\title{
PERAN CALON PENDIDIK FISIKA SMA TERHADAP PENGUATAN NILAI PENDIDIKAN KARAKTER MELALUI PEMBELAJARAN PROBLEM POSING BERBASIS PERMAINAN TRADISIONAL SAMAWA SEBAGAI SALAH SATU STRATEGI MENGHADAPI TANTANGAN MEA
}

\author{
${ }^{1}$ Riza Kurnia Lestari, ${ }^{2}$ Ardin Al Yussufa, ${ }^{3}$ Tursina Ratu \\ ${ }^{1)}$ Prodi Pendidikan Fisika UNSA, (riza.icha1996@yahoo.co.id) \\ ${ }^{2)}$ Pendidikan Bahasa dan Sastra Indonesia (ardin.mss@gmail.com) \\ ${ }^{3)}$ Dosen Pendidika Fisika, (tursina_ratu@yahoo.com)
}

\begin{abstract}
Abstrak
Salah satu tujuan negara Indonesia adalah mengembangkan potensi peserta didik untuk memiliki kecerdasan, kepribadian dan akhlak mulia. Ketiga faktor tersebut memberi kontribusi penting dalam mencapai tujuan negara. Peserta didik dapat mengembangkan kecerdasan, kepribadian dan akhlak mulia jika diberikan penguatan nilai karakter. Karakter sangat berperan terhadap kecerdasan, kepribadian dan akhlak mulia peserta didik. Nilai karakter dapat ditanamkan pada peserta didik melalui pendidikan karakter. Kondisi ini tidak lepas dari peran calon pendidik. Calon pendidik dapat menerapkan pembelajaran Problem Posing berbasis permainan tradisional samawa. Permainan tradisional samawa merupakan salah satu bagian dari kearifan lokal daerah Sumbawa yang memiliki banyak nilai karakter, serta dapat dimanfaatkan sebagai media pembelajaran, kususnya fisika. Dengan demikian, peserta didik sebagai generasi penerus bangsa memiliki strategi dalam mempersiapkan diri menghadapi tantangan secara global, khususnya tantangan MEA.
\end{abstract}

Kata Kunci: Pendidikan Karakter, Problem Posing, Permainan Tradisional Samawa

\section{PENDAHULUAN}

Indonesia merupakan negara kepulauan yang penuh dengan kekayaan serta keragaman budaya, ras, suku bangsa, kepercayaan, agama, bahasa daerah, dan masih banyak lainnya. Meskipun penuh dengan keragaman budaya, Indonesia tetap satu sesuai dengan semboyan nya, Bhineka Tunggal Ika yang artinya "meskipun berbeda-beda tetapi tetap satu jua". Keragaman budaya turut serta didukung oleh wilayah Negara Kesatuan Republik Indonesia yang terpisah wilayah-wilayahnya oleh lautan.

Setiap wilayah memiliki budaya masing-masing. Budaya merupakan pola hidup yang berkembang dan dimemiliki bersama diwariskan dari generasi ke generasi. Budaya terbentuk dari banyak unsur termasuk,agama, politik, adat istiadat, bahasa, pakaian, dan karya seni.Indonesia merupakan wilayah yang menganut kebudayaan timur yang mementingkan kerohanian, perasaan, gotong-royong dan menjaga keharmonisan antar manusia, alam dan tuhan. Berkembangnya pengaruh budaya asing di Indonesia, mengikis karakter budaya secara perlahan. Salah satu contoh dari pengaruh budaya asing adalah gaya hidup modern, seperti budaya hidup konsumtif. Budaya hidup konsumtif tidak lepas dari peran media iklan yaitu media elektronik, media cetak dan media sosial.

Budaya hidup konsumtif pada masyarakat Indonesia menyebabkan masyarakatIndonesia baik dari tingkat dewasa, remaja dan anak-anak semakin bergantung terhadap produk luar negeri. Kebergantungan ini mempengaruhi masyarakat khususnya di kalangan remaja. Disadari atau tidak, sedikit banyak masyarakat khususnya remaja mengalami demoralisasi. Sebagai contoh konkrit, tawuran antar remaja/peserta didik antar sekolah, pemakaian drugs, balapan motor dan mobil secara liar.

Masuk dan berkembangnya globalisasi di Indonesia membuat budaya yang ada di Indonesia memudar. Salah satunya di Sumbawa, Sumbawa merupakan daerah yang jauh dari pusat pengembangan. Masuknya globalisasi ke Sumbawa tentunya akan memiliki dampak negatif, yang mana masyarakat Sumbawa pada umumnya bisa dikatakan tidak siap 
menerima budaya luar. Sehingga budaya yang ada di Sumbawa bisa memudar dan membuat pola prilaku masyarakat Sumbawa yang tidak baik. Yang mana budaya tersebut bisa menentukan sifat masyarakat Sumbawa.

Salah satu budaya yang memudar saat ini di Sumbawa yaitu budaya permainan tradisional anak Sumbawa. Akhir-akhir ini jarang sekali ditemukan anak-anak Sumbawa yang memainkan permainan tradisional bahkan tidak ditemukan sama sekali pada waktu ini. Mereka lebih memainkan playstation, mobil remot dan sebagainya. Padahal dalam permainan tersebut tertanam nilai-nilai karakter yang dapat membentuk karakter anak seperti jujur, kerja sama, tanggung jawab, kekompakan dan lainnya. Yang mana saat ini pendidikan karakter sangat penting dan lagi booming dibicarakan. Mengingat banyak orang yang tidak memiliki karakter sehingga menghasilkan generasi masyarakat yang tidak baik dalam masyarakat, seperti korupsi dan sebagainya. Oleh karena itu, permainan tradisional anak sumbawa tersebut perlu dilestarikan mengingat pentingnya hal tersebut bagi anakanak. Selain budaya seperti tari, terdapat pula budaya permainan tradisional yang sering dimainkan oleh anak-anak Sumbawa. Diantaranya permainan kelar ,permainan kelereng,permainan Karet, permainan step dan sebagainya.

UU Sisdiknas No. 20 tahun 2003 menyatakan bahwa tujuan pendidikan nasional adalah mengembangkan potensi peserta didik untuk memiliki kecerdasan, kepribadian dan akhlak mulia.Ke tiga faktor tersebut memberi kontribusi penting dalam mencapai tujuan negara. Peserta didik dapat mengembangkan kecerdasan, kepribadian dan akhlak mulia jika diberikan penguatan nilai karakter. Karakter sangat berperan terhadap kecerdasan, kepribadian dan akhlak mulia peserta didik. Nilai karakter dapat ditanamkan pada peserta didik melalui pendidikan karakter. Kondisi ini tidak lepas dari peran mahasiswa sebagai calon pendidik.

Calon pendidik nantinya akan berperan sebagai pendidik. Pendidikan menjadi kebutuhan dasar dan sepanjang hayat bagi setiap individu. Dikatakan calon "pendidik" memiliki arti lebih dibandingkan arti calon "pengajar". Memang tugas pendidik atau yang lebih akrab dengan sebutan "guru" salah satunya adalah mengajar atau memberikan materi di depan para siswanya, memberikan penilaian atas ulangan harian dan ujian yang telah diberikan, dan mengambil kesimpulan atas kemampuan akademik siswa berdasarkan hasil akhir yang direkap dalam rapor.

Mahasiswa merupakan generasi penerus bangsa yang menjadi pondasi sekaligus panglima dalam perang IPTEK. Mahasiswa sebagai perwakilan generasi muda yang akan membawa bangsa ini menjadi harum atau malah sebaliknya yakni terpuruk karena ketertinggalan. Sebagai mahasiswa yang diproses untuk menjadi seorang pendidik dengan harapan bisa menjadi guru yang professional.

Dalam praktiknya di lapangan, pendidikan kerap mengalami sakit kepala alias pusing saat menghadapi sikap dan karakter peserta didik yang beragam. Disinilah peran kita sesungguhnya yakni tidak sekedar memberikan materi pelajaran kemudian selesai dan pulang. Menghadapi peserta didik khususnya remaja memang gampang-gampang susah.mereka memiliki banyak kemauan karena banyak kreatifitasnya mulai berkembang dan adanya keinginan untuk mewujudkan semua yang ada dipikirannya.

\section{PEMBAHASAN}

Pendidikan mempunya peran dan tanggung jawab penting untuk membawa perubahan dalam diri manusia atau peserta didik. Dengan majunya ilmu pengetahuan dan perubahan yang terjadi dalam masyarakat memberikan dampak sangat jelas dalam kepribadian setiap manusia. Terjadinyan perubahan karakter menyebabkan pengikisan nilai-nilai moral yang sudah ada dalam peserta didik.

Pendidikan karakter sebagaimana telah menjadi suatu pembelajaran penting di setiap sekolah khususnya SMA. Dalam perkembangan sering muncul bebagai macam tantangan bagaimana penguatan nilai pendidikan karakter dalam dunia pendidikan untuk menghadi 
tantangan MEA. Diperlukannya peran calon guru khususnya fisika SMA untuk memperkuat nilai pendidikan karakter.

Guru adalah pendidik dan pengajar pada pendidikan anak jalur sekolah atau pendidikan formal, pendidikan dasar, dan pendidikan menengah. Dengan tugas utama mendidik mengajar, membimbing, mengarahkan, melatih dan mengevaluasi peserta didik secara professional. Seorang guru yang professional tidak hanya memiliki kemampuan teknis edukatif tetapi juga harus memiliki kepribadian yang dapat diandalkan sehingga menjadi sosok panutan bagi siswa, keluarga maupun masyarakat.

Agar seorang guru dapat menjalankan tugasnya secara professional dalam pembelajaran, seorang guru hendaknya memiliki beberapa peranan dalam proses belajar mengajar, diantaranya yaitu : (1) Guru sebagai Fasilitator, Wina Senjaya(2008) mengemukakan bahwa agar guru dapat mengoptimalkan perannya sebagai fasilitator, maka guru perlu memahami hal-hal yang berhubungan dengan pemanfaatan berbagai media dan sumber belajar. untuk mewujudkan dirinya sebagai fasilitator, guru perlu menyediakan sumber dan media belajar yang cocok dan beragam dalam setiap kegiatan pembelajaran, dan tidak menjadikan dirinya sebagai satu-satunya sumber belajar bagi para siswanya. (2) Guru sebagai Motivator, Sejalan dengan pergeseran makna pembelajaran dari pembelajaran yang berorientasi kepada guru (teacher oriented) ke pembelajaran yang berorientasi kepada siswa (student oriented), maka peran guru dalam proses pembelajaran pun mengalami pergeseran, salah satunya adalah penguatan peran guru sebagai motivator (Akhmad Sudrajat, 2012). (3) Guru sebagai Inovator, Guru sebagai Inovator, guru berfungsi melakukan kegiatan kreatif, menemukan strategi, metode, cara-cara, atau konsep-konsep yang baru dalam pengajaran. sebagai inovator harus mampu mencari, menemukan dan melaksanakan berbagai pembaharuan di sekolah.

Pengabdian seorang guru adalah merupakan kontribusi yang sangat berarti dan dapat dirasakan manfaatnya bagi dunia pendidikan khususnya dalam peguatan nilai pendidikan karakter bangsa. Masuk dan berkembangnya globalisasi di Indonesia membuat budaya yang ada di Indonesia memudar. Salah satunya di Sumbawa, Sumbawa merupakan daerah yang jauh dari pusat pengembangan. Masuknya globalisasi ke Sumbawa tentunya akan memiliki dampak negatif, yang mana masyarakat Sumbawa pada umumnya bisa dikatakan tidak siap menerima budaya luar. Sehingga budaya yang ada di Sumbawa bisa memudar dan membuat pola prilaku masyarakat Sumbawa yang tidak baik. Yang mana budaya tersebut bisa menentukan sifat masyarakat Sumbawa.

Salah satu budaya yang memudar saat ini di Sumbawa yaitu budaya permainan tradisional anak Sumbawa. Akhir-akhir ini jarang sekali ditemukan anak-anak Sumbawa yang memainkan permainan tradisional bahkan tidak ditemukan sama sekali pada waktu ini. Mereka lebih memainkan playstation, mobil remot dan sebagainya. Padahal dalam permainan tersebut tertanam nilai-nilai karakter yang dapat membentuk karakter anak seperti jujur, kerja sama, tanggung jawab, kekompakan dan lainnya. Yang mana saat ini pendidikan karakter sangat penting dan lagi booming dibicarakan. Mengingat banyak orang yang tidak memiliki karakter sehingga menghasilkan generasi masyarakat yang tidak baik dalam masyarakat, seperti korupsi dan sebagainya. Oleh karena itu, permainan tradisional anak sumbawa tersebut perlu dilestarikan mengingat pentingnya hal tersebut bagi anakanak. Selain budaya seperti tari, terdapat pula budaya permainan tradisional yang sering dimainkan oleh anak-anak Sumbawa. Diantaranya permainan kelar, permainan kelereng, permainan Karet, permainan step dan sebagainya.

Permainan tradisional SAMAWA menjadi salah satu media penguat nilai pendidikan karakter. Menurut sukirman(2004), Permainan Tradisional anak merupakan unsur kebudayaan, karena mampu memberikan pengaruh terhadap perkembangan kejiwaan, sifat, dan kehidupan sosial anak. oleh karena itu permaian tradisional SAMAWA merupakan aset budaya untuk mempertahankan eksistensi dan identitas di tengah-tengah perkembangan zaman. 
Permainan Tradisional yang semakin hari semakin hilang di telan perkembangan zaman, sesungguhnya menyimpan sebuah keunikan, kesenian dan manfaat yang lebih besar seperti kerja sama tim, olahraga, terkadang juga membantu meningkatkan daya otak. Berbeda dengan permainan anak zaman sekarang yang hanya duduk diam memainkan permainan dalam layar monitor dan sebagainya.

Menguatnya arus globalisasi di Indonesia yang membawa pola kehidupan dan hiburan baru, mau tidak mau, memberikan dampak tertentu terhadap kehidupan sosial budaya masyarakat. Termasuk di dalamnya berbagai macam permainan tradisional anak. Sementara itu, kenyataan dilapangan dewasa ini memperlihatkan adanya tanda tanda yang kurang menggembirakan yakni semakin kurangnya permaianan tradisional anak yang ditampilkan, sehingga akan berakibat pada kepunahan (Sukirman ). Banyaknya kegunaan permainan bagi proses pembelajaran perlu adanya pelestarian terhadap keutuhan permainan tersebut. Mengenal permainan tradisional SAMAWA bermain kelereng, step, kelar dan lain-lain di masa muda, akan mengantarkan mereka pada permainan yang bermanfaat dalam kegiatan belajar untuk meraih prestasi di masa yang akan datang.

Pendidikan karakter dapat dikaitkan dengan pembelajaran problem posing berbasis permainan tradisional SAMAWA sebagai salah satu strategi menghadapi tantangan MEA. Pembelajaran problem posing merupakan model pembelajaran yang mengharuskan siswa menyusun pertanyaan sendiri atau memecahkan suatu soal menjadi pertanyaan-pertanyaan yang lebih sederhana mengacu pada soal tersebut.

Model pembelajaran problem posing ini mulai dikembangkan di tahun 1997 oleh Lyn D. English, dan awal mulanya diterapkan dalam mata pelajaran matematika. Selanjutnya, model ini dikembangkan pula pada mata pelajaran yang lain.

Pada prinsipnya, model pembelajaran problem posing adalah suatu model pembelajaran yang mewajibkan para siswa untuk mengajukan soal sendiri melalui belajar soal (berlatih soal) secara mandiri. Penerapan model pembelajaran problem posing di kelas dapat dilakukan sebagai berikut :1.Guru menjelaskan materi pelajaran kepada para siswa. Penggunaan alat peraga untuk memperjelas konsep sangat disarankan. 2. Guru memberikan latihan soal secukupnya. 3. Siswa diminta mengajukan 1 atau 2 buah soal yang menantang, dan siswa yang bersangkutan harus mampu menyelesaikannya. Tugas ini dapat pula dilakukan secara kelompok.Pada pertemuan berikutnya, secara acak, guru menyuruh siswa untuk menyajikan soal temuannya di depan kelas. Dalam hal ini, guru dapat menentukan siswa secara selektif berdasarkan bobot soal yang diajukan oleh siswa. 4. Guru memberikan tugas rumah secara individual.

Model pembelajaran problem posing (pengajuan soal) dapat dikembangkan dengan memberikan suatu masalah yang belum terpecahkan dan meminta siswa untuk menyelesaikannya. Guru dalam rangka mengembangkan model pembelajaran problem posing (pengajuan soal) yang berkualitas dan terstruktur dalam pembelajaran dapat menerapkan prinsip-prinsip dasar, di antaranya: Pengajuan soal harus berhubungan dengan apa yang dimunculkan dari aktivitas siswa di dalam kelas; Pengajuan soal harus berhubungan dengan proses pemecahan masalah siswa; Pengajuan soal dapat dihasilkan dari permasalahan yang ada dalam permainan tradisional SAMAWA seperti permainan kelereng, step dan kelar.

Permainan kelereng, tanpa disadari saat kita bermain kelereng maka kita juga menerapkan konsep tiga hukum gerak yang dirumuskan oleh Isaac newton. Hukum I newton berbunyi "jika resultan gaya yang bekerja pada benda sama dengan nol maka benda yang mula-mula diam akan tetap diam dan benda yang bermula-mula bergerak lurus beraturan akan tetap bergerak lurus beraturan". Contohnya ketika pertama kita menembakkan kelereng ke atas permukaan tanah, lama kelamaan kelereng akan bergerak lambat dan pada akhirnya akan berhenti.

Hukum II newton, "percepatan yang ditimbulkan oleh gaya yang bekerja pada benda berbanding lurus dengan besar gayanya dan berbanding terbalik dengan massa benda. 
Contohnya ketika ingin membuat kelereng bergerak lebih cepat maka kita juga harus mengeluarkan gaya atau tenaga yang lebih besar kepada kelereng.

Hukum III Newton berbunyi "Jika benda pertama memberikan gaya pada benda kedua maka benda kedua akan memberikan gaya balasan yang besarnya sama tetapi arahnya berlawanan.Contohnya ketika kita menembak kelereng kita kepada kelereng teman kita, lalu terjadi pantulan yang disebabkan karena sentuhan kedua kelereng tersebut. Gaya aksi yaitu gaya yang kita berikan kepada kelereng kita terhadap kelereng teman kita. Sedangkan gaya reaksi yaitu gaya yang diberikan kelereng teman kita kepada kelereng kita sebagai akibat dari gaya dari kelereng kita tadi sehingga kelerengnya tersebut akan memantul.

Permainan step, pada permainan step hukum Hooke yang berlaku pada karet step yang digunakan untuk membidik sasaran. Hukum Hooke adalah hukum mengenai gaya dalam bidang ilmu fisika yang yang terjadi karena sifat elastisitas dari sebuah pir atau pegas. Besarnya gaya hooke ini secara proposional akan berbanding lurus dengan jarak pergerakan pegas dari posisi normalnya.

Selain hukum hooke permainan step juga berlaku gerak parabola, dimana ketika kita menembakan peluruh ke sasaran, gerak peluruh menuju kesasaran merupakan gerak parabola. Gerak parabola merupakan perpaduan antara gerak lurus beraturan pada arah mendatar/horizontal dan gerak lurus berubah beraturan pada arah vertikal.

Pada permainan step peluruh diberikan gaya dengan menggunakan karet agan meluncur atau berpindah tempat menuju sasaran. Hal ini merupakan suatu bentuk usaha oleh step terhadap peluruh. Karet step yang kita regangkan memiliki energi potensial. Karet step dapat melontarkan peluruh karena adanya energi potensial pada karet yang diregangkan

\section{SIMPULAN}

Pendidikan mempunya peran dan tanggung jawab pending untuk membawa perubahan dalam diri manusia atau peserta didik. Dengan majunya ilmu pengetahuan dan perubahan yang terjadi dalam masyarakat memberikan dampak sangat jelas dalam kepribadian setiap manusia. Terjadinyan perubahan karakter menyebabkan pengikisan nilai-nilai moral yang sudah ada dalam peserta didik.

Pendidikan karakter sebagaimana telah menjadi suatu pembelajaran penting di setiap sekolah khususnya SMA. Dalam perkembangan sering muncul bebagai macam tantangan bagaimana penguatan nilai pendidikan karakter dalam dunia pendidikan untuk menghadi tantangan MEA. Diperlukannya peran calon guru khususnya fisika SMA untuk memperkuat nilai pendidikan karakter.

\section{DAFTAR PUSTAKA}

Lestyarini, Beniati. 2012.'Penumbuhan Semangat Kebangsaan untuk Memperkuat Karakter Indonesia melalui Pembelajaran Bahasa" dalam Jurnal Pendidikan Karakter. Yogyakarta: LPPMP UNY.

Misbach, I.H. 2006. Peran Permainan Tradisional yang Bermuatan Edukatif Dalam Menyumbang Pembentukan Karakter dan Identitas Bangsa, Jurusan Psikologi, UPI.

Saptono. 2011. Dimensi-dimensi pendidikan karakter. Salatiga: Esensi.

Wagiran. 2012. "Pengembangan KarakterBerbasis Kearifan Lokal Hamemayu Hayuning Bawana (Identifikasi Nilainilai Karakter Berbasis Budaya)" dalam Jurnal Pendidikan Karakter. Yogyakarta: LPPMP UNY. 